REVIEW

\title{
Syndromes and constitutional chromosomal abnormalities associated with Wilms tumour
}

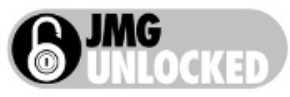

This article is available free on JMG online via the JMG Unlocked open access trial, funded by the Joint Information Systems Committee. For further information, see http://img.bmijournals.com/cgi/content/ full $/ 42 / 2 / 97$
See end of article for authors' affiliations

Correspondence to: Prof Nazneen Rahman, Section of Cancer Genetics, Institute of Cancer Research, 15 Cotswold Road, Sutton Surrey SM2 5NG, UK; nazneen.rahman@icr.ac. uk

Received 13 February 2006 Revised version received 7 April 2006

Accepted for publication 10 April 2006

Published Online First

11 May 2006
Multiple nephrogenic rests throughout the kidney are sometimes present and can be referred to as nephroblastomatosis.

The dramatic advances in the treatment of Wilms tumour are such that long term survival is now the norm: exceeding $90 \%$ for disease localised to the abdomen (stages $1-3$ ), and over $70 \%$ in metastatic disease (stage 4 ). ${ }^{7}$ The treatment of Wilms tumour is determined both by stage and histological classification of the tumour, with treatment protocols varying between countries. Surgical resection is complemented in the majority of individuals by chemotherapy. Currently in the United Kingdom around $30 \%$ of individuals with Wilms tumour also receive radiotherapy.

A wide range of syndromes, congenital anomalies, and constitutional chromosomal abnormalities have been reported in association with Wilms tumour. Data from the British National Registry of Childhood Tumours showed that around $9 \%$ of individuals with Wilms tumour have a congenital anomaly, and a study of long term childhood cancer survivors revealed a syndrome diagnosis in 23 of 136 individuals (17\%) with Wilms tumour. ${ }^{8}$ This is the highest proportion seen in any childhood malignancy.

The aim of this article is to document the syndromes, congenital abnormalities, and constitutional chromosomal aberrations reported to occur in association with Wilms tumour, and to review the evidence for an increased risk of Wilms tumour in these conditions. Accurate estimation of risk can be difficult in the absence of large prospective studies, which are rarely feasible in conditions reported in association with Wilms tumour, many of which are very rare. Where Wilms tumour is a diagnostic criterion for the condition, risk estimation is particularly difficult. It is probable that cases of a syndrome with Wilms tumour are more likely to be reported than cases without tumours, and that such reporter bias leads to an overestimate of the tumour risk. Because of this difficulty of accurate risk estimation we have generally given a qualitative risk estimate (for example, high, moderate, or low) rather than a precise figure.

For a comprehensive assessment of conditions reported in association with Wilms tumour, we undertook extensive searches for relevant articles using the PubMed, Online Mendelian

Abbreviations: BWS, Beckwith-Wiedemann syndrome; $\mathrm{IHH}$, isolated hemihypertrophy; WAGR, Wilms-aniridiagenitourinary-mental retardation 
Inheritance in Man (OMIM), and the Winter-Baraitser dysmorphology databases (see electronic database section at the end of the paper). To facilitate searches we created a database of more than 8000 references with "Wilms tumour" or "nephroblastoma" in the title or abstract, which we downloaded from PubMed. We then searched this database for generic terms such as "syndrome" and "malformation". We also reviewed the references of identified papers for additional relevant literature.

\section{CONDITIONS WITH AN INCREASED RISK OF WILMS TUMOUR}

The conditions in which there is conclusive evidence of an increased risk of Wilms tumour are shown in table 1. They can be broadly classified into five groups: WT1 associated phenotypes caused by mutations or deletions of the WTI gene; familial Wilms tumour; overgrowth conditions; tumour predisposition syndromes in which Wilms tumour is one of a number of benign or malignant tumours that can occur; and constitutional chromosomal disorders.

\section{WT 1 associated syndromes}

The Wilms tumour 1 (WTl) gene is located at $11 \mathrm{pl3}$ and encodes a zinc finger transcription factor with a crucial role in renal and gonadal development. It consists of a C-terminal zinc finger DNA binding domain and an $\mathrm{N}$-terminal transactivational domain, and occurs in multiple alternatively spliced isoforms. ${ }^{10}$ WT1 acts as a classic tumour suppressor gene and the wild type allele is somatically inactivated in tumours occurring in individuals with constitutional WTI mutations or deletions. The median age of Wilms tumour diagnosis in such individuals is younger than in unselected series of Wilms tumour cases $(\sim 1$ year in WT1 associated syndromes, 3 to 4 years in unselected Wilms tumour series) and tumours are more likely to be bilateral $(38 \%$ in WT1 associated syndromes; $5 \%$ in unselected Wilms tumour series). The tumours also frequently contain intralobar nephrogenic rests and are often of stromal predominant histology. ${ }^{11}$

Constitutional WTI defects are associated with a range of overlapping phenotypes characterised by various combina-

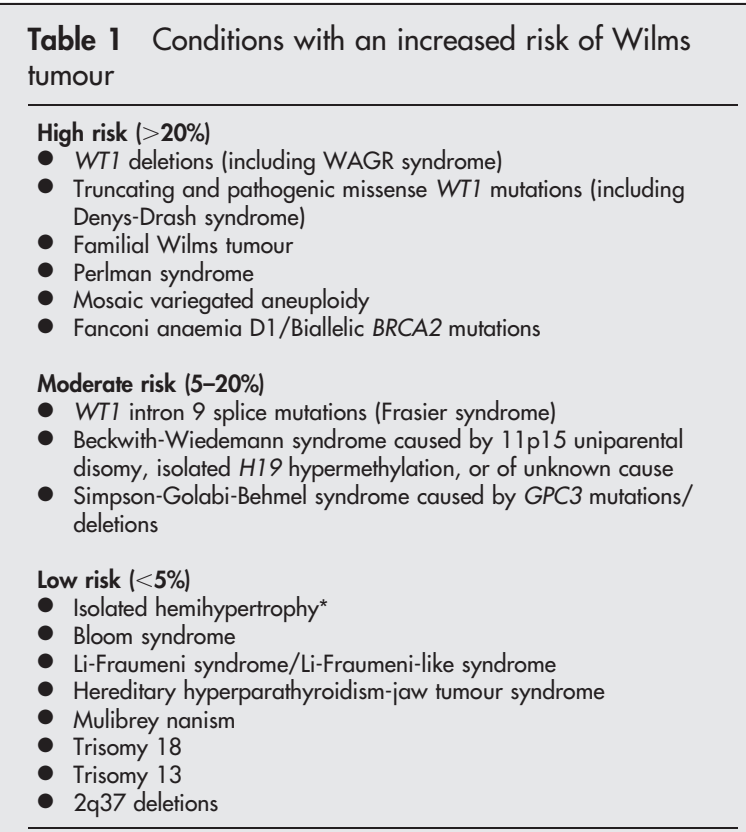

*Individuals with hemihypertrophy caused by 11 p15 uniparental disomy or isolated $\mathrm{H} 19$ hypermethylation are at moderate risk of Wilms tumour. WAGR, Wilms-aniridia-genitourinary-mental. tions of three cardinal features: Wilms tumour, genitourinary abnormalities, and renal dysfunction.

\section{WAGR syndrome}

WAGR (Wilms-aniridia-genitourinary-mental retardation) syndrome (OMIM 194072) was the first WT1 associated condition to be characterised and is found in around 7-8/ 1000 individuals with Wilms tumour. ${ }^{12}$ It manifests with complete or partial aniridia, ambiguous external genitalia and cryptorchidism in males, and intellectual impairment. The risk of renal failure is high, affecting around $40 \%$ of individuals by the age of 20 years (median age of diagnosis 15 years). ${ }^{13}$ Heterozygous constitutional microdeletions at $11 \mathrm{pl} 3$ encompassing both WTI and PAX6 are responsible for WAGR, with the WTI deletion causing the genitourinary features and Wilms tumour predisposition and deletion of PAX6 resulting in aniridia. Approximately $30 \%$ of individuals with aniridia carry microdeletions that encompass $W T 1$, with the remainder usually harbouring smaller deletions or intragenic PAX6 mutations. ${ }^{14}$ These latter individuals are not at increased risk of Wilms tumour. Rare individuals with $11 \mathrm{p} 13$ microdeletions involving WTI but excluding PAX6 have been reported and present with Wilms tumour or genitourinary abnormalities, or both, but without aniridia. ${ }^{15} 16$

\section{Denys-Drash syndrome}

Denys-Drash syndrome (OMIM 194080) classically describes the triad of Wilms tumour, nephropathy, and genitourinary abnormalities in males, which may be severe enough to result in pseudohermaphroditism. ${ }^{17}{ }^{18}$ The nephropathy results from a characteristic mesangial sclerosis and typically presents with hypertension and proteinuria, usually progressing to renal failure and requiring renal replacement therapy before the age of 10 years. ${ }^{19}$ Genitourinary abnormalities in males are very common but are highly variable in severity, ranging from mild hypospadias to female external genitalia and streak gonads. While some XX individuals show gonadal dysgenesis, the majority have no gonadal abnormality and present with nephropathy or Wilms tumour. Most individuals with classic Denys-Drash syndrome harbour missense mutations affecting critical residues in the zinc finger domains that are implicated in DNA binding and are believed to act in a dominant negative fashion. ${ }^{11}$

\section{Frasier syndrome}

Frasier syndrome (OMIM 136680) describes the association of nephropathy with gonadal dysgenesis and gonadoblastoma. $^{20}$ The nephropathy is typically a focal segmental glomerulosclerosis, which progresses to renal failure by the second or third decade. ${ }^{21}$ The genitourinary abnormalities in males are usually severe, and sex reversal in XY individuals is common. Frasier syndrome is caused by mutations in intron 9 that alter WTl splicing and prevent the formation of WTI isoforms that normally include a linker of three amino acids (KTS) between the third and fourth zinc fingers encoded by exons 9 and 10, respectively. ${ }^{22}$

\section{Other WTI associated phenotypes}

WT1 mutations have also been reported in individuals with either one or two of the three cardinal features. Such individuals are more likely to harbour intragenic truncating WT1 mutations than missense mutations in the zinc finger domains. Several individuals with Wilms tumour in the absence of any other phenotypic abnormalities have been reported, but only around 2\% of non-syndromic Wilms tumour patients carry germline WTl mutations..$^{23}$ Most are de novo, but rare families with a WTI mutation/deletion resulting in more than one individual with Wilms tumour in the family are known. ${ }^{24-27}$ 
The risk of Wilms tumour varies in different WT1 associated conditions. The Wilms tumour risk in individuals with microdeletions, missense mutations affecting zinc finger domains, or mutations that result in premature protein truncation is high-probably at least 50\%. ${ }^{114}$ Missense mutations outside the zinc finger domains may be rare non-pathogenic polymorphisms, and caution should be exercised in their interpretation, particularly if they are not de novo. The risk of Wilms tumour in individuals with intron 9 splicing mutations is considerably lower than for other mutations: only four of 48 individuals reported with Frasier syndrome $(8 \%)$ developed Wilms tumour. ${ }^{28-30}$ However, the risk of gonadal tumours is high in Frasier syndrome, whereas such tumours are rare in individuals with other classes of WT1 abnormality.

\section{Familial Wilms tumour}

Only 1-2\% of Wilms tumour cases cluster within families, but the underlying causes of these rare pedigrees are heterogeneous and complex. A minority of families with more than one individual with Wilms tumour are associated with syndromes described elsewhere in this review: WTI mutations/deletions (four families), ${ }^{24-27}$ mosaic variegated aneuploidy syndrome (two families), ${ }^{31}$ biallelic BRCA2 mutations (one family), ${ }^{32}$ and $11 \mathrm{pl} 5$ defects (one family). ${ }^{33}$ However, the underlying cause of most familial Wilms tumour is currently unknown.

An autosomal dominant Wilms tumour predisposition gene, FWT1, has been mapped to $17 \mathrm{q} 21$ but has not been identified. ${ }^{34}{ }^{35}$ Wilms tumour in FWTI linked families tends to be diagnosed at a later age and more advanced stage than sporadic Wilms tumour (median age at diagnosis six years). The penetrance of FWT1 mutations is only around 30\% and the wild-type allele is not lost in tumours. These features suggest that FWTI does not operate as a classical tumour suppressor gene. ${ }^{36}$ It has been proposed that there is a second familial Wilms tumour gene, FWT2, on 19q13. The evidence in favour of this locus is suggestive but not conclusive, as no single family with a LOD (log of odds) score in excess of 3 has been identified. Although combining the LOD scores of five smaller families gave a LOD score $>3$ in the original paper, some of these families were also consistent with linkage at $F W T 1$, and families unlinked at 19q13 were excluded from the analysis. ${ }^{37}$ Furthermore, several families not linked to WT1, FWT1, or FWT2 exist, indicating further genetic heterogeneity in familial Wilms tumour. ${ }^{38}$ As a consequence of this genetic heterogeneity, the penetrance, age distribution, and tumour histology observed in familial Wilms tumour pedigrees shows marked intrafamilial and interfamilial variation.

\section{Childhood overgrowth syndromes}

Childhood overgrowth syndromes are a heterogeneous, overlapping, and poorly defined collection of conditions. It is sometimes assumed that any condition involving overgrowth in childhood has an increased risk of malignancy. In part this may be because high birth weight has been identified as a possible risk factor for Wilms tumour in several mainly population based studies. ${ }^{39-43}$ However, the importance of birth weight as a risk factor outside the context of overgrowth disorders that predispose to Wilms tumour is unclear. Moreover, conclusive evidence of an increased risk of Wilms tumour has only been demonstrated in a minority of overgrowth conditions, and in some overgrowth conditions the incidence of this tumour has been shown to be very low. ${ }^{44} 45$ There is also no evidence that children with nonspecific overgrowth have an increased tumour risk. Therefore, the Wilms tumour risk of overgrowth conditions should be evaluated on a syndrome specific rather than a collective basis.
Beckwith-Wiedemann syndrome

Beckwith-Wiedemann syndrome (BWS; OMIM 130650) is an overgrowth disorder with a prevalence of around 1 in $14000 .^{46}$ In addition to prenatal and postnatal overgrowth, characteristic clinical findings include macroglossia, anterior abdominal wall defects, ear creases and pits, neonatal hypoglycaemia, and hemihypertrophy. Non-malignant abnormalities of the renal tract include nephromegaly, multiple renal cysts, medullary sponge kidney, medullary dysplasia, hydronephrosis, and renal stone disease. ${ }^{47}$ The overall risk of childhood malignancy in BWS has been estimated to be $4-21 \%$. Wilms tumour is the most frequently reported tumour, affecting $1-8 \%$ of individuals. ${ }^{4-52}$ Bilateral Wilms tumour (17\%) and perilobar nephrogenic rests $(60 \%)$ occur at increased frequency compared with unselected series of Wilms tumour patients ( $5 \%$ and $15 \%$, respectively). ${ }^{5653}$

BWS is caused by dysregulation of imprinted genes at chromosome $11 \mathrm{pl} 5$ that control prenatal and childhood growth. Various genetic and epigenetic abnormalities at 11 pl5 have been demonstrated in BWS. Full exposition of these is beyond the scope of this article and the reader is referred to recent reviews. ${ }^{45}{ }^{54}$ Isolated hypomethylation of a differentially methylated region, known as KvDMRl, is the commonest cause of BWS, found in around $50 \%$ of cases. Mosaic paternal uniparental disomy of $11 \mathrm{pl} 15$ is present in around $20 \%$ of individuals and is particularly associated with hemihypertrophy. Isolated hypermethylation of the H19 differentially methylated region and mutations in the growth suppressor, CDKNIC each occur in about $5 \%$ of cases. CDKNIC mutations can result in familial BWS if the mutations are maternally transmitted. Chromosomal aberrations affecting 11 p15 including translocations, inversions, duplications, and rarely ring chromosomes, and microdeletions are found in a small number of individuals $(1-2 \%)$. These are reviewed elsewhere and are not individually documented here. ${ }^{54}$ The cause of BWS is unknown in about $20 \%$ of cases.

Several studies have evaluated tumour risk in the epigenetic subgroups of BWS, although the risk is somewhat difficult to quantify because some studies preferentially include cases with tumours while others do not report tumour types. ${ }^{55-60}$ Overall, current data suggest the risk of Wilms tumour is appreciably increased with defects that result in an absolute increase of growth promoters (such as uniparental disomy and isolated hypermethylation of the H19 differentially methylated region), but is either not increased or only modestly increased with defects that solely result in decrease in growth suppressors (such as isolated hypomethylation of KvDMRl or CDKNIC mutation). ${ }^{61}$ The $20 \%$ of individuals without an identified underlying cause are at increased risk of Wilms tumour. Importantly, the largest group of individuals with BWS-those with isolated loss of methylation at KvDMRl-do not appear to be at increased risk of Wilms tumour. ${ }^{55-60} 11 \mathrm{p} 15$ epigenotyping in BWS therefore not only provides molecular confirmation of the diagnosis in many individuals, but also facilitates identification of the subset of individuals with BWS who are at increased risk of Wilms tumour.

\section{Simpson-Golabi-Behmel syndrome}

Simpson-Golabi-Behmel syndrome (OMIM 312870) is an $\mathrm{X}$ linked overgrowth disorder associated with coarse facial features, skeletal and cardiac abnormalities, accessory nipples, and intellectual impairment in some individuals. Renal dysplasia or nephromegaly is reported in around $30 \%$ of cases and hydronephrosis and hydroureter are also described. ${ }^{62}$ Mutations or deletions of Glypican-3 (GPC3) at Xq26 cause Simpson-Golabi-Behmel syndrome and are found in about $70 \%$ of affected individuals. ${ }^{63}{ }^{64}$ The cause in the remainder is unknown, although one family with a more severe phenotype 
(but no cases of Wilms tumour) was linked to Xp22. ${ }^{65}$ GPC3 is a cell surface heparan sulphate proteoglycan that modulates the effects of several growth factors and interacts with the Wnt pathway. ${ }^{66}{ }^{67}$ Although it was initially proposed that GPC3 could directly interact with insulin-like growth factor 2 (IGF2), thus providing a functional link between the phenotypically overlapping conditions of BWS and Simpson-Golabi-Behmel syndrome, ${ }^{68}$ there is no current evidence linking GPC3 with the IGF2 pathway ${ }^{69}$ Of the 35 patients with GPC3 mutations reported, three (9\%) developed Wilms tumour. ${ }^{70}{ }^{71}$ Other embryonal tumours can also rarely occur. There is no evidence to suggest an increased risk of Wilms tumour in female GPC3 mutation/deletion carriers or in individuals with a clinical diagnosis of Simpson-GolabiBehmel syndrome but without GPC3 mutations.

\section{Isolated hemihypertrophy}

Isolated hemihypertrophy (OMIM 235000; also referred to as isolated hemihyperplasia) is a poorly defined term referring to asymmetrical overgrowth that results in one region of the body being larger than its counterpart on the other side. Hemihypertrophy is associated with various genetic syndromes (including Beckwith-Wiedemann, proteus, KlippelTrenaunay-Weber, and cutis-marmorata-telangiectatica-congenita) but the majority of individuals present without signs of another genetic condition and are said to have isolated (or idiopathic) hemihypertrophy ( $\mathrm{IHH})$. Estimates of the prevalence of IHH vary from 1 in 13000 to 1 in $86000 . .^{72-74}$ However, the distinction of $\mathrm{IHH}$ from normal variation in limb width/length is unclear and there is no consensus on diagnostic criteria. This is exemplified by data showing that the hemihypertrophy was so subtle in more than $50 \%$ of individuals reported with tumours in association with $\mathrm{IHH}$ that it was only diagnosed at tumour diagnosis or later. ${ }^{75} 76$ Lack of clarity about diagnostic criteria together with a predilection to describe any degree of asymmetry in children with tumours as "hemihypertrophy" makes the true frequency of IHH or the proportion of individuals that develop tumours very difficult to estimate.

A prospective study of 168 patients with IHH reported 10 tumours in nine individuals, of whom five $(3 \%)$ had Wilms tumour, suggesting that the risk of Wilms tumour is modestly increased. ${ }^{77}$ Notably, tumours occur at equal frequency in the larger and smaller kidney in asymmetrical individuals. Abnormalities at 11 p15 that are known to cause BWS (see above) have been reported in $20-35 \%$ of those with hemihypertrophy in two small series of cases of hemihypertrophy and childhood tumours (five of 14 and three of 15 , respectively $)^{98}$ and in another series of individuals without tumours (eight of 27). ${ }^{79}$ It would be anticipated that such individuals would carry similar risks of Wilms tumour as those with BWS because they have the same epigenetic defect. It is unclear whether IHH patients without $11 \mathrm{pl} 5$ defects are at increased risk of Wilms tumour. There have been isolated reports of individuals with karyotypic abnormalities such as trisomy 8 mosaicism and diploid-triploid mosaicism in IHH. ${ }^{80}$ However, the cause of the majority of cases is unknown.

\section{Perlman syndrome}

Perlman syndrome (OMIM 267000) is an autosomal recessive condition characterised by prenatal overgrowth with polyhydramnios, visceromegaly, facial dysmorphism, developmental delay, cryptorchidism, renal dysplasia, Wilms tumour, and high mortality in infancy. ${ }^{81}$ The cause is unknown, although a GPC3 mutation was identified in one family, emphasising the clinical overlap with Simpson-GolabiBehmel syndrome. ${ }^{64}{ }^{82}$ Seven of the 21 cases reported (33\%) developed Wilms tumour ${ }^{83-89}$ and nephroblastomatosis or renal hamartomas, or both, have been identified in all but one of the infants born at term. ${ }^{89}$ Of the eight individuals who survived beyond 28 days, five developed Wilms tumour. No other tumours have been reported.

\section{Tumour predisposition syndromes}

Constitutional mutations in at least 70 genes are known to confer susceptibility to benign or malignant tumours, ${ }^{90}$ but only a small minority is associated with an increased risk of Wilms tumour. In addition, the occurrence of familial clustering of Wilms tumour with other malignancies (such as neuroblastoma) that cannot be accounted for by mutations in known genes suggests the existence of as yet uncharacterised tumour predisposition syndromes which increase the risk of Wilms tumour (Rahman N, unpublished data).

\section{Mosaic variegated aneuploidy}

Mosaic variegated aneuploidy (OMIM 257300) is an autosomal recessive disorder characterised by constitutional mosaicism for losses and gains of whole chromosomes. Biallelic mutations in BUBIB-which encodes BUBRl, a key component of the mitotic spindle checkpoint-cause around $50 \%$ of cases (Hanks et al ${ }^{91}$ and Rahman N, unpublished data). Clinical features are variable and include microcephaly, growth retardation, developmental delay, cataracts, and congenital heart defects. Childhood cancers-including Wilms tumour, rhabdomyosarcoma and haematological malignancies-have been reported in a number of patients. Wilms tumour is the most commonly reported cancer, present in 10 of 40 published cases $(25 \%) .^{31}{ }^{92-96}$

\section{Biallelic BRCA2 mutations/Fanconi anaemia D1}

Fanconi anaemia is an autosomal recessive condition characterised by short stature, radial ray defects, abnormal skin pigmentation, and bone marrow failure. Myelodysplastic syndrome and acute myeloid leukaemia often occur in childhood and there is an increased risk of solid tumours in those who survive to adulthood. ${ }^{97}$ Cells from individuals with Fanconi anaemia show increased chromosome breakage when exposed to DNA cross linking agents. At least 12 complementation groups have been defined and 11 genes identified..$^{97} 98$

BRCA2 encodes a protein involved in repair of double strand DNA breaks. ${ }^{99}$ Heterozygous (monoallelic) constitutional mutations in $B R C A 2$ predispose to breast and ovarian cancers in adulthood, but not to childhood cancers. Biallelic BRCA2 mutations cause Fanconi anaemia subgroup Dl (OMIM 605724). Affected children are less likely to have skeletal abnormalities and their cells often show spontaneous chromosome breaks, in contrast to other subgroups. The cancer spectrum is also distinctive with a high risk of childhood solid tumours, particularly Wilms tumour and brain tumours. ${ }^{32} 100$ Five of the 24 reported cases $(21 \%)$ developed Wilms tumour. ${ }^{32} 101102$ The risk of Wilms tumour in other Fanconi anaemia subgroups does not appear to be increased.

\section{Bloom syndrome}

Bloom syndrome (OMIM 210900) is an autosomal recessive chromosomal instability disorder characterised by short stature, sun sensitive telangiectatic erythematous skin lesions, areas of hyperpigmented and hypopigmented skin, immunodeficiency, and a characteristic facial appearance. It is caused by biallelic mutations in $B L M,{ }^{103}$ which encodes a DNA helicase important in protection against aberrant recombination between sister chromatids and homologous chromosomes. Bloom syndrome is associated with a range of malignancies and around 50\% of cases develop cancer. ${ }^{104}$ Fewer than 200 individuals with Bloom syndrome have been reported, six $(>3 \%)$ of whom developed Wilms tumour, suggesting that the risk of this tumour is low. ${ }^{104-107}$ 


\section{Li-Fraumeni syndrome}

Li-Fraumeni syndrome (OMIM 151623) is an autosomal dominant tumour predisposition syndrome characterised by a high incidence of a range of tumours, notably breast cancer, sarcomas, adrenocortical cancer, and brain tumours. ${ }^{108}$ Heterozygous germline mutations in TP53-a gene with a crucial role in the induction of cell cycle arrest, apoptosis, and DNA repair in response to a variety of stimuli-are identifiable in around $70 \%$ of families with classical Li-Fraumeni syndrome. ${ }^{109110}$ Wilms tumour is not one of the cardinal tumours included in the diagnostic criteria for this syndrome, but has been reported in at least six families harbouring TP53 mutations, and in several mutation negative families which fulfil the Li-Fraumeni syndrome and Li-Fraumeni-like diagnostic criteria. ${ }^{11-118}$ Five of the six TP53 mutations reported in association with Wilms tumour affect splicing. Such mutations account for only $4 \%$ of all reported germline TP53 mutations. ${ }^{116}$ This suggests that the risk of Wilms tumour in Li-Fraumeni syndrome may be influenced by the type of TP53 mutation. However, the Wilms tumour risk overall appears to be low, both in families with an identified TP53 mutation and in those with either classic Li-Fraumeni or a Li-Fraumeni-like phenotype in which TP53 mutations have not been found.

\section{Hereditary hyperparathyroidism-jaw tumour syndrome}

Hereditary hyperparathyroidism-jaw tumour syndrome (OMIM 145001) is an autosomal dominant condition characterised by fibro-osseous lesions of the maxilla and mandible and parathyroid tumours. ${ }^{119}$ Heterozygous inactivating mutations in the HRPT2 gene are causative. ${ }^{120}$ Preliminary evidence suggests that HRPT2 plays a role in transcriptional elongation and RNA processing. ${ }^{121}$ More than 100 affected individuals from around 40 families have been reported. A variety of renal abnormalities occur including renal cysts, benign mixed epithelial-stromal tumours, renal cortical adenomas, and papillary renal cell carcinomas. ${ }^{122-125}$ Wilms tumour has been reported in three individuals $(<3 \%)$, one of whom apparently developed bilateral Wilms tumour at the exceptionally late age of 53 years. ${ }^{122} 126$

\section{Mulibrey nanism}

Mulibrey nanism (muscle-liver-brain-eye nanism; OMIM 253250 ) is an autosomal recessive disease with a phenotype that includes short stature, a distinctive facial appearance, yellowish dots in the peripheral retina, hepatomegaly, hepatic hamartomas, and ovarian fibrothecomas. ${ }^{127}{ }^{128}$ Mutations in TRIM37, a member of the tripartite motif subfamily of zinc finger proteins, are causative. ${ }^{129}$ TRIM37 has been shown to have ubiquitin E3 ligase activity, although its substrates have not been identified. ${ }^{130}$ At least 110 individuals with mulibrey nanism have been reported, three of whom $(<3 \%)$ developed Wilms tumour. ${ }^{127} 131132$

\section{Constitutional chromosomal abnormalities}

In addition to karyotypic abnormalities affecting $11 \mathrm{pl} 3$ and $11 \mathrm{pl5}$, at least three other constitutional chromosome abnormalities are associated with an increased risk of Wilms tumour.

\section{Trisomy 18}

Trisomy 18 (Edwards syndrome) occurs in about 1 in 3000 live births and usually results in multiple congenital malformations. ${ }^{133}$ Over $90 \%$ of affected individuals die within the first year of life. Renal abnormalities, particularly horseshoe kidney, are common, occurring in more than half the cases. ${ }^{134}$ There have been 12 reports of Wilms tumour in individuals with trisomy $18 .{ }^{135-143}$ Furthermore, perilobar nephrogenic rests or nephroblastomatosis, or both, have been reported in a number of cases in the absence of Wilms tumour. ${ }^{144}$ of interest, the median age at diagnosis of Wilms tumour in trisomy 18 (five years) is greater than in sporadic Wilms tumour. Given the high early mortality of trisomy 18, the risk of Wilms tumour to long term survivors is clearly increased.

\section{Trisomy 13}

Trisomy 13 (Patau syndrome) occurs in around 1 in 10000 live births and is associated with multiple congenital malformations including renal tract abnormalities. ${ }^{133}$ Neonatal and infant mortality is very high, with a median survival of one week. ${ }^{145}$ Two cases with Wilms tumour have been reported, one of which occurred within a horseshoe kidney. ${ }^{141}{ }^{146}$ Given the very high early mortality in trisomy 13, the risk to those surviving the neonatal period is likely to be increased.

\section{2q37 deletion}

Three individuals with Wilms tumour in association with constitutional terminal deletions of chromosome 2q have been reported. Two had isolated deletions of $2 \mathrm{q} 37$ with the proximal breakpoint at 2q37.1. ${ }^{147148}$ The third had a paternally inherited unbalanced chromosomal translocation that resulted in monosomy $2 \mathrm{q} 37$ and trisomy 15q22-qter. ${ }^{141}$ All three children had congenital gonadal/urogenital abnormalities. At least 66 individuals have been reported with isolated terminal deletions of chromosome 2q. The most frequently reported breakpoint is 2 q37.3 and only 15 cases have been reported with a breakpoint at 2q37.1. ${ }^{149}$ Seven of the 66 cases $(11 \%)$ with terminal $2 q$ deletions are reported to have gonadal/urogenital abnormalities, including four of 15 (27\%) with a breakpoint at 2q37.1. The overall risk of Wilms tumour in individuals with a 2 q37 deletion may be as high as $3 \%$ (two of 66). However, it is possible that the risk is primarily to individuals with deletions extending to 2q37.1, who may therefore be at higher risk.

\section{CONDITIONS IN WHICH AN INCREASED RISK OF WILMS TUMOUR IS UNCERTAIN OR UNLIKELY}

In a large number of the conditions reported in association with Wilms tumour an increased risk of this tumour is uncertain or unlikely (table 2). For relatively common conditions in which only a few cases of Wilms tumour have been reported it is likely that the occurrence of the tumour is coincidental and that the conditions are not associated with an increased risk. For example, fragile X syndrome, Marfan syndrome, and tuberous sclerosis are all relatively common conditions in which only a single individual with Wilms tumour has been reported, while it has been reported in two cases of Down syndrome. ${ }^{155} 156160171182$ Wilms tumour has been reported in seven individuals with neurofibromatosis type $1 .{ }^{175}$ However, neurofibromatosis type 1 occurs in around 1 in 3000 of the general population, and several large population based, ${ }^{186}$ cohort, ${ }^{187}{ }^{188}$ and cancer registry studies ${ }^{189}$ have found no evidence of an increased risk for this tumour. For other conditions a small increased risk cannot be excluded on the basis of available data, but the absolute risk of Wilms tumour is very small. For example, Sotos syndrome-an overgrowth disorder caused by haploinsufficiency of NSDI-was reported to be associated with Wilms tumour and other cancers, based on cases with a clinical diagnosis of the syndrome, which can be difficult for those without experience of the condition. ${ }^{190}$ The advent of molecular diagnosis has shown that the incidence of Wilms tumour in individuals with NSDI abnormalities is very low. ${ }^{191}$ Similarly, four individuals with Turner syndrome were found among an American series of 5854 cases with Wilms tumour, two of which occurred in a horseshoe kidney. ${ }^{141}$ No case of Wilms tumour was identified in a British series of 400 
Table 2 Phenotypes reported in association with Wilms tumour in which an increased risk is uncertain or unlikely

\begin{tabular}{|c|c|c|c|c|}
\hline Disorder & OMIM & $\begin{array}{l}\text { No of cases } \\
\text { (families) }\end{array}$ & Further details & References \\
\hline Androgen insensitivity syndrome & 300068 & 1 & & 150 \\
\hline Angelman syndrome & 105830 & 1 & $\begin{array}{l}\text { Loss of SNRPN methylation; no evidence of } 15 q 11 \text { deletion or } \\
\text { UPD }\end{array}$ & Unpublished* \\
\hline Branchial cleft anomalies-Wilms tumour & - & $3(1)$ & $\begin{array}{l}\text { Mother and two daughters with Wilms tumour and bilateral } \\
\text { auditory canal stenosis; mother had hemihypertrophy of left } \\
\text { breast, daughters had eye abnormalities }\end{array}$ & 151 \\
\hline Cleidocranial dysostosis & 119600 & 1 & & 9 \\
\hline Cornelia de Lange syndrome & 122470 & 1 & Two cases have also been reported with nephrogenic rests ${ }^{152}$ & 153 \\
\hline Currarino syndrome & 176450 & 1 & Presacral ectopic Wilms tumour & 154 \\
\hline Down syndrome & 190685 & $2(2)$ & & 155,156 \\
\hline Epidermal naevus syndromes & - & $3(3)$ & & $157-159$ \\
\hline Fragile- $X$ syndrome & 309550 & 1 & & 160 \\
\hline Greig cephalopolysyndactyly syndrome & 175700 & 1 & $\begin{array}{l}\text { Dominant history of Greig syndrome, one individual with } \\
\text { Wilms tumour }\end{array}$ & Unpublished* \\
\hline Hay-Wells syndrome & 106260 & 1 & $\begin{array}{l}\text { Bilateral Wilms tumour; familial reticulate pigmentation of skin } \\
\text { also present }\end{array}$ & 161 \\
\hline $\begin{array}{l}\text { Holoprosencephaly and neuronal migration } \\
\text { defects }\end{array}$ & - & 1 & & 162 \\
\hline Hyperprolinaemia type 1 & 239500 & 1 & Renal abnormalities present in three generations of the family & 163 \\
\hline Imperforate anus with rectourethral fistula & - & 1 & & 164 \\
\hline Incontinentia pigmenti & 308300 & $2(2)$ & & 165,166 \\
\hline Juvenile polyposis syndrome & 174900 & 1 & $\begin{array}{l}\text { BMPR IA splice-site mutation; colonic carcinoma, adrenal } \\
\text { hamartoma, Ebstein anomaly }\end{array}$ & 167 \\
\hline Klippel-Trenaunay syndrome & 149000 & 1 & Bilateral nephroblastomatosis also reported in one case ${ }^{168}$ & 169 \\
\hline $\begin{array}{l}\text { Macrocephaly-cutis marmorata telangiectatica } \\
\text { congenita }\end{array}$ & & & & \\
\hline $\begin{array}{l}\text { congenita } \\
\text { Marfan syndrome }\end{array}$ & $\begin{array}{l}602501 \\
154700\end{array}$ & 1 & & $\begin{array}{l}170 \\
171\end{array}$ \\
\hline Marshall-Smith syndrome & 602535 & 1 & Wilms tumour developed after case published & 172 \\
\hline Moebius syndrome & 157900 & 1 & Arthrogryposis and mega cisterna magna & 173 \\
\hline Monopedal syrenomelia & - & 1 & $\begin{array}{l}\text { Left renal agenesis, absent external genitalia, imperforate } \\
\text { anus, absence of greater omentum, patent ductus arteriosus }\end{array}$ & 174 \\
\hline Neurofibromatosis type 1 & 162200 & $7(7)$ & & 175 \\
\hline Noonan syndrome & 163950 & 1 & & 9 \\
\hline Osteogenesis imperfecta & - & 1 & Molecular defect not defined; hemihypertrophy & 9 \\
\hline Peters anomaly & 604229 & 1 & & 176 \\
\hline Pierre Robin sequence & 261800 & 1 & Developmental delay & 177 \\
\hline Poland anomaly & 173800 & 1 & Ipsilateral shortening of lower limb & 178 \\
\hline Polycythaemia, ichthyosis, and ear & & & & \\
\hline malformations & - & 1 & & 179 \\
\hline Prader-Willi syndrome & 176270 & 1 & & 180 \\
\hline Russell-Silver syndrome & 180860 & 1 & & 181 \\
\hline Tuberous sclerosis & 191100 & 1 & & 182 \\
\hline Turner syndrome & - & $6(6)$ & & $141,183,184$ \\
\hline VATER association & 192350 & 1 & & 185 \\
\hline
\end{tabular}

individuals with Turner syndrome, ${ }^{192}$ and only a single Wilms tumour was reported among a Danish series of 597 individuals with Turner syndrome. ${ }^{183}$ These data suggest that the risk of Wilms tumour in Turner syndrome is close to the population risk.

In the case of rarer conditions reported in association with Wilms tumour (table 2), and the many published individuals with this tumour whose phenotypes are not readily classifiable, ${ }^{8} 9193194$ it is difficult to clarify whether reports represent coincidental findings or reflect an increased risk of Wilms tumour. Similarly, several individuals with Wilms tumour and a discrete constitutional karyotypic abnormality have been reported (table 3). In at least some of these individuals it is likely that the chromosomal abnormality alters the function of a Wilms tumour predisposition gene. For example, two distinct but overlapping abnormalities of chromosome $15 \mathrm{q}$ have been reported in individuals with Wilms tumour. ${ }^{207}{ }^{208}$ Both result in an increased number of copies of IGFIR, which may be implicated in the occurrence of Wilms tumour in these individuals.

Various congenital abnormalities have been suggested to be associated with an increased risk of Wilms tumour outside the context of syndromes and constitutional chromosomal abnormalities. ${ }^{210-213}$ While an increased risk can rarely be excluded on the basis of available data it is clear that the magnitude of any increased risk can only be small. For example, horseshoe kidney was found in 35 of 8617 American Wilms tumour patients $(0.41 \%)$ (excluding cases with chromosomal abnormalities), compared with a population incidence of around 1 in $400(0.25 \%) .{ }^{213}$ These data are consistent with either no increased risk or a very small increased risk. Similarly, a systematic review of 1041 children with multicystic dysplastic kidney found no case of histologically confirmed Wilms tumour. ${ }^{214}$ This suggests that the previously reported increased Wilms tumour risk ${ }^{212}$ either does not exist or is very small. An excess of cardiac defects, particularly septal defects, has been reported in some unselected series of Wilms tumour cases.8 210215216 However, cardiac defects are found with increased frequency in a number of Wilms tumour predisposition syndromes, and their importance outside these conditions remains unclear. ${ }^{12}{ }^{64}$ Cervical rib abnormalities have also been proposed to be associated with Wilms tumour, ${ }^{211}$ but data from a blinded case-control study suggest that the risk of Wilms tumour is not significantly increased in these cases. ${ }^{217}$ 
Table 3 Constitutional chromosomal abnormalities reported in association with Wilms tumour on one occasion

\begin{tabular}{|c|c|c|c|c|}
\hline Abnormality & $\begin{array}{l}\text { No of } \\
\text { cases }\end{array}$ & Further details of cytogenetic abnormality & Other clinical features & References \\
\hline$t(1 ; 16)(p 22 ; p 13.2)$ & 1 & Apparently balanced & Unilateral Wilms tumour & 141 \\
\hline del(1)(p36pter) & 1 & & Unilateral Wilms tumour & Unpublished ${ }^{*}$ \\
\hline $\begin{array}{l}\text { del(1)(p36.1 pter) dup } \\
\text { (1)(q24qter) }\end{array}$ & 1 & $\begin{array}{l}\text { De novo mosaic unbalanced } t(1 ; 1)(p 36.1 ; q 23) ; \\
\text { present in } 9 / 40 \text { amniocytes, } 7 / 96 \text { normal kidney } \\
\text { cells and all tumour cells examined }\end{array}$ & $\begin{array}{l}\text { Bilateral Wilms tumour; congenital cardiac } \\
\text { malformations, agenesis of corpus callosum, facial } \\
\text { dysmorphism, hypopigmented skin lesions, } \\
\text { developmental delay }\end{array}$ & 195 \\
\hline $\operatorname{dup}(1)(q 2 ? 2 q 2 ? 3)$ & 1 & & & 196 \\
\hline$t(1 ; 7)(q 42 ; p 15)$ & 1 & $\begin{array}{l}\text { De novo, apparently balanced; translocation } \\
\text { interrupts PTH-B1 at } 7 p \text { and Obscurin at } 1 q \text {; } \\
\text { monsomy } 7 p \text {, trisomy } 7 q \text { in tumour }\end{array}$ & $\begin{array}{l}\text { Unilateral Wilms tumour; nephrogenic rest in } \\
\text { contralateral kidney, multiple skeletal abnormalities, } \\
\text { transient thrombocyłopenia }\end{array}$ & 197 \\
\hline $\operatorname{del}(2)(p 11.2 p 12)$ & 1 & Maternally inherited; $7.5 \mathrm{Mb}$ deletion & Speech delay, mild dysmorphic features & 198 \\
\hline$t(5 ; 6)(q 21 ; q 21)$ & 1 & De novo, apparently balanced & Bilateral synchronous Wilms tumours & 199 \\
\hline$t(7 ; 19)(q 11.2 ; q 13.3)$ & 1 & De novo, apparently balanced & $\begin{array}{l}\text { Bilateral synchronous Wilms tumours; enlarged } \\
\text { cisterna magnal, thick corpus callosum, facial } \\
\text { dysmorphism }\end{array}$ & 200 \\
\hline$t(7 ; 13)(q 36 ; q 13)$ & 1 & De novo, apparently balanced; paternal in origin & $\begin{array}{l}\text { Unilateral Wilms tumour; facial dysmorphism, } \\
\text { hydrocephalus, developmental delay, umbilical } \\
\text { hernia, bilateral inguinal herniae with testicular } \\
\text { ectopia }\end{array}$ & 201 \\
\hline $8 p+$ & 1 & $\begin{array}{l}\text { Additional material of unknown origin on } 8 p \text {; } \\
\text { possible } 8 p \text { duplication }\end{array}$ & Single kidney & 141 \\
\hline $\operatorname{del}(9)(q 22 q 31)$ & 1 & $\begin{array}{l}\text { De novo, deletion includes PTCH; PTCH expression } \\
\text { increased in fumours }\end{array}$ & Synchronous rhabdomyosarcoma & 202 \\
\hline$t(9 ; 12)(q 22.3 ; q 15)$ & 1 & De novo, apparently balanced & & 203 \\
\hline $\operatorname{del}(11)(q 14.1 \mathrm{q} 21)$ & 1 & De novo & Horseshoe kidney; perilobar nephrogenic rests & 204 \\
\hline $\operatorname{del}(12)(q 11 q 13.1)$ & 1 & $\begin{array}{l}\text { De novo, paternal in origin; no } \mathrm{LOH} \text { at } 12 q \text { in } \\
\text { tumour }\end{array}$ & $\begin{array}{l}\text { Unilateral Wilms tumour; growth delay, } \\
\text { developmental delay, facial dysmorphism }\end{array}$ & 205 \\
\hline $\begin{array}{l}\text { dup (12)(q24.3qter) } \\
\text { del(22)(q13.3qter) }\end{array}$ & 1 & $\begin{array}{l}\text { Maternally inherited unbalanced } \\
t(12 ; 22)(q 24.33 ; q 13.31)\end{array}$ & $\begin{array}{l}\text { Unilateral Wilms tumour; developmental delay, } \\
\text { overgrowth }\end{array}$ & 206 \\
\hline Tetrasomy 15q24.3-qłer & 1 & $\begin{array}{l}\text { Mosaic abnormality in lymphocytes: } 68 \% \\
\text { intrachromosomal triplication 15q24-qter; } 7 \% \\
\text { inverted duplication 15q24.3-qter fused to 3qter; } \\
25 \% \text { normal }\end{array}$ & $\begin{array}{l}\text { Unilateral Wilms tumour; intellectual impairment, } \\
\text { body asymmetry, arachnodactyly, facial } \\
\text { dysmorphism }\end{array}$ & 207 \\
\hline Tetrasomy 15q25.3-qter & 1 & $\begin{array}{l}\text { Supernumerary marker chromosome present in } \\
19 / 20 \text { lymphocytes and all tumour cells examined }\end{array}$ & $\begin{array}{l}\text { Bilateral synchronous Wilms tumours; apparent } \\
\text { Shprintzen-Goldberg syndrome: macrosomia, long } \\
\text { digits, craniosynostosis }\end{array}$ & 208 \\
\hline $\begin{array}{l}\text { Ring chromosome of } \\
\text { unknown origin }\end{array}$ & 2 & $\begin{array}{l}\text { Mother and two affected children harboured ring } \\
\text { chromosome of unknown origin }\end{array}$ & $\begin{array}{l}\text { Two siblings affected with Wilms tumour: one was } \\
\text { affected unilaterally, the other bilaterally }\end{array}$ & 209 \\
\hline
\end{tabular}

\section{CONCLUSIONS}

This review provides clear evidence of an increased risk of Wilms tumour in a broad range of syndromes and chromosomal disorders (table 1). The clinical heterogeneity of these disorders is matched by the functional diversity of their causative genes. The absence of any known functional interaction between most of these genes demonstrates the diversity of molecular pathways by which Wilms tumorigenesis occurs.

Emerging evidence continues to modify the spectrum of conditions associated with predisposition to Wilms tumour and to refine the level of risk. Of particular interest is the recent evidence that different mechanisms of epigenetic dysregulation can have a substantial impact on the risk of Wilms tumour. The continued clarification of the phenotypic groups and subgroups predisposed to Wilms tumour will foster further insights into the molecular basis of these conditions and Wilms tumorigenesis, and will facilitate the diagnosis of underlying disorders in children with Wilms tumour. In addition, it provides a basis for the management and counselling of a child with a possible Wilms tumour predisposition syndrome. While the methods and inclusion criteria for Wilms tumour screening are contentious and beyond the scope of this review, the inclusion of any patient group must be considered in the context of their level of risk. $^{218}$

\section{ELECTRONIC DATABASES USED TO IDENTIFY CONDITIONS REPORTED IN ASSOCIATION WITH WILMS TUMOUR}

- Pubmed. http://www.ncbi.nlm.nih.gov/entrez/query.fcgi? $\mathrm{db}=$ PubMed 
- OMIM. http://www.ncbi.nlm.nih.gov/entrez/query.fcgi? $\mathrm{db}=$ OMIM

- Winter-Baraitser Dysmorphology database. Winter RM, Baraitser M. Oxford: Oxford University Press, 2004.

\section{ACKNOWLEDGEMENTS}

This work was supported by the Institute of Cancer Research (UK). RHS is supported by the Kadoorie Charitable Foundation. The Childhood Cancer Research Group receives funding from the Department of Health and the Scottish Ministers. The views expressed in the publication are those of the authors and not necessarily those of the Department of Health and the Scottish Ministers.

\section{Authors' affiliations}

R H Scott, N Rahman, Section of Cancer Genetics, Institute of Cancer Research, Sutton, Surrey, UK

C A Stiller, Childhood Cancer Research Group, Department of Paediatrics, University of Oxford, Oxford, UK

L Walker, Department of Medical Genetics, Addenbrooke's Hospital, Cambridge, UK

Conflicts of interest: none declared

\section{REFERENCES}

Stiller CA, Parkin DM. International variations in the incidence of childhood renal tumours. Br J Cancer 1990;62:1026-30.

2 Breslow NE, Olson J, Moksness J, Beckwith JB, Grundy P. Familial Wilms' tumor: a descriptive study. Med Pediatr Oncol 1996;27:398-403.

3 Breslow N, Beckwith JB, Ciol M, Sharples K. Age distribution of Wilms' tumor: report from the National Wilms' Tumor Study. Cancer Res 1988:48:1653-7.

4 Hentrich MU, Meister P, Brack NG, Lutz LL, Hartenstein RC. Adult Wilms' tumor. Report of two cases and review of the literature. Cancer 1995;75:545-51.

5 Ritchey ML, Shamberger RC, Hamilton T, Haase G, Argani P, Peterson S. Fate of bilateral renal lesions missed on preoperative imaging: a report from the National Wilms Tumor Study Group. J Urol 2005;174:1519-21.

6 Beckwith JB, Kiviat NB, Bonadio JF. Nephrogenic rests, nephroblastomatosis, and the pathogenesis of Wilms' tumor. Pediatr Pathol 1990;10:1-36.

7 Pritchard-Jones K. Controversies and advances in the management of Wilms' tumour. Arch Dis Child 2002;87:241-4.

8 Narod SA, Hawkins MM, Robertson CM, Stiller CA. Congenital anomalies and childhood cancer in Great Britain. Am J Hum Genet 1997;60:474-85.

9 Merks JH, Caron HN, Hennekam RC. High incidence of malformation syndromes in a series of 1,073 children with cancer. Am J Med Genet A 2005; 134:132-43.

10 Haber DA, Sohn RL, Buckler AJ, Pelletier J, Call KM, Housman DE. Alternative splicing and genomic structure of the Wilms tumor gene WT1. Proc Natl Acad Sci USA 1991;88:9618-22.

11 Royer-Pokora B, Beier M, Henzler M, Alam R, Schumacher V, Weirich A, Huff $V$. Twenty-four new cases of WT1 germline mutations and review of the literature: genotype/phenotype correlations for Wilms tumor development. Am J Med Genet A 2004; 127A:249-57.

12 Breslow NE, Norris R, Norkool PA, Kang T, Beckwith JB, Perlman EJ, Ritchey ML, Green DM, Nichols KE. Characteristics and outcomes of children with the Wilms tumor-aniridia syndrome: a report from the National Wilms Tumor Study Group. J Clin Oncol 2003;21:4579-85.

13 Breslow NE, Takashima JR, Ritchey ML, Strong LC, Green DM. Renal failure in the Denys-Drash and Wilms' tumor-aniridia syndromes. Cancer Res 2000;60:4030-2.

14 Muto R, Yamamori S, Ohashi H, Osawa M. Prediction by FISH analysis of the occurrence of Wilms tumor in aniridia patients. Am J Med Genet 2002; 108:285-9

15 Royer-Pokora B, Ragg S, Heckl-Ostreicher B, Held M, Loos U, Call K, Glaser T, Housman D, Saunders G, Zabel B. Direct pulsed field gel electrophoresis of Wilms' tumors shows that DNA deletions in $11 \mathrm{p} 13$ are rare. Genes Chromosomes Cancer 1991;3:89-100.

16 Baird PN, Santos A, Groves N, Jadresic L, Cowell JK. Constitutional mutations in the WT1 gene in patients with Denys-Drash syndrome. Hum Mol Genet 1992;1:301-5.

17 Denys P, Malvaux P, Van den BH, Tanghe W, Proesmans W. [Association of an anatomo-pathological syndrome of male pseudohermaphroditism, Wilms' tumor, parenchymatous nephropathy and XX/XY mosaicism]. Arch Fr Pediatr 1967;24:729-39.

18 Drash A, Sherman F, Hartmann WH, Blizzard RM. A syndrome of pseudohermaphroditism, Wilms' tumor, hypertension, and degenerative renal disease. J Pediatr 1970;76:585-93.

19 Eddy AA, Maver SM. Pseudohermaphroditism, glomerulopathy, and Wilms tumor (Drash syndrome): frequency in end-stage renal failure. J Pediatr 1985; 106:584-7.
20 Frasier S, Bashore R, Mosier H. Gonadoblastoma associated with pure gonadal dysgenesis in monozygous twins. J Pediatr 1964;64:740-5.

21 Demmer L, Primack W, Loik V, Brown R, Therville N, McElreavey K. Frasier syndrome: a cause of focal segmental glomerulosclerosis in a 46,XX female. J Am Soc Nephrol 1999;10:2215-18.

22 Barbaux S, Niaudet P, Gubler MC, Grunfeld JP, Jaubert F, Kuttenn F, Fekete CN, Souleyreau-Therville N, Thibaud E, Fellous M, McElreavey K. Donor splice-site mutations in WT1 are responsible for Frasier syndrome. Nat Genet 1997; 17:467-70.

23 Little SE, Hanks SP, King-Underwood L, Jones C, Rapley EA, Rahman N, Pritchard-Jones K. Frequency and heritability of WTI mutations in nonsyndromic Wilms' tumor patients: a UK Children's Cancer Study Group Study. J Clin Oncol 2004;22:4140-6.

24 Yunis JJ, Ramsay NK. Familial occurrence of the aniridia-Wilms tumor syndrome with deletion 11 p13-14.1. J Pediatr 1980;96:1027-30.

25 Pelletier J, Bruening W, Li FP, Haber DA, Glaser T, Housman DE. WT mutations contribute to abnormal genital system development and hereditary Wilms' tumour. Nature 1991;353:431-4.

26 Kaplinsky C, Ghahremani M, Frishberg Y, Rechavi G, Pelletier J. Familial Wilms' tumor associated with a WT1 zinc finger mutation. Genomics 1996;38:451-3

27 Zirn B, Wittmann S, Gessler M. Novel familial WT1 read-through mutation associated with Wilms tumor and slow progressive nephropathy. Am J Kidney Dis 2005;45:1100-4.

28 Coppes MJ, Campbell CE, Williams BR. The role of WT1 in Wilms tumorigenesis. FASEB J 1993;7:886-95.

29 Barbosa AS, Hadjiathanasiou CG, Theodoridis C, Papathanasiou A, Tar A Merksz M, Gyorvari B, Sultan C, Dumas R, Jaubert F, Niaudet P, MoreiraFilho CA, Cotinot C, Fellous M. The same mutation affecting the splicing of WT1 gene is present on Frasier syndrome patients with or without Wilms' tumor. Hum Mutat 1999;13:146-53.

30 Loirat C, Andre JL, Champigneulle J, Acquaviva C, Chantereau D Bourquard R, Elion J, Denamur E. WT1 splice site mutation in a $46, X X$ female with minimal-change nephrotic syndrome and Wilms' tumour. Nephrol Dial Transplant 2003; 18:823-5

31 Kaiii T, Ikeuchi T, Yang ZQ, Nakamura Y, Tsuji Y, Yokomori K, Kawamura M, Fukuda S, Horita S, Asamoto A. Cancer-prone syndrome of mosaic variegated aneuploidy and total premature chromatid separation: report of five infants. Am J Med Genet 2001;104:57-64.

32 Reid S, Renwick A, Seal S, Baskcomb L, Barfoot R, Jayatilake H, PritchardJones K, Stratton MR, Ridolfi-Luthy A, Rahman N. Biallelic BRCA2 mutations are associated with multiple malignancies in childhood including familial Wilms tumour. J Med Genet 2005;42:147-51

33 Prawitt D, Enklaar T, Gartner-Rupprecht B, Spangenberg C, Oswald M, Lausch E, Schmidtke P, Reutzel D, Fees S, Lucito R, Korzon M, Brozek I, Limon J, Housman DE, Pelletier J, Zabel B. Microdeletion of target sites for insulator protein CTCF in a chromosome 11 p15 imprinting center in Beckwith-Wiedemann syndrome and Wilms' tumor. Proc Natl Acad Sci U S A 2005; 102:4085-90

34 Rahman N, Arbour L, Tonin P, Renshaw J, Pelletier J, Baruchel S, PritchardJones K, Stratton MR, Narod SA. Evidence for a familial Wilms' tumour gene (FWT1) on chromosome 17q12-q21. Nat Genet 1996;13:461-3.

35 Rahman N, Abidi F, Ford D, Arbour L, Rapley E, Tonin P, Barton D, Batcup G, Berry J, Cotter F, Davison V, Gerrard M, Gray E, Grundy R, Hanafy M, King D, Lewis I, Ridolfi LA, Madlensky L, Mann J, O'Meara A, Oakhill T, Skolnick M, Strong L, Stratton MR. Confirmation of FWT1 as a Wilms' tumour susceptibility gene and phenotypic characteristics of Wilms' tumour attributable to FWT1. Hum Genet 1998; 103:547-56.

36 Rahman N, Arbour L, Tonin P, Baruchel S, Pritchard-Jones K, Narod SA, Stratton MR. The familial Wilms' tumour susceptibility gene, FWT1, may not be a tumour suppressor gene. Oncogene 1997; 14:3099-102.

37 McDonald JM, Douglass EC, Fisher R, Geiser CF, Krill CE, Strong LC, Virshup D, Huff V. Linkage of familial Wilms' tumor predisposition to chromosome 19 and a two-locus model for the etiology of familial tumors. Cancer Res 1998;58:1387-90.

38 Rapley EA, Barfoot R, Bonaiti-Pellie C, Chompret A, Foulkes W, Perusinghe N, Reeve A, Royer-Pokora B, Schumacher V, Shelling A, Skeen J, de Tourreil S, Weirich A, Pritchard-Jones K, Stratton MR, Rahman N. Evidence for susceptibility genes to familial Wilms tumour in addition to WT1, FWT1 and FWT2. Br J Cancer 2000;83:177-83.

39 Leisenring WM, Breslow NE, Evans IE, Beckwith JB, Coppes MJ, Grundy P. Increased birth weights of National Wilms' Tumor Study patients suggest a growth factor excess. Cancer Res 1994;54:4680-3.

40 Heuch JM, Heuch I, Kvale G. Birth characteristics and risk of Wilms' tumour: a nationwide prospective study in Norway. Br J Cancer 1996;74:1 148-51.

41 Yeazel MW, Ross JA, Buckley JD, Woods WG, Ruccione K, Robison LL. High birth weight and risk of specific childhood cancers: a report from the Children's Cancer Group. J Pediatr 1997;131:671-7.

42 Schuz J, Kaletsch U, Meinert R, Kaatsch P, Michaelis J. High-birth weight and other risk factors for Wilms tumour: results of a population-based casecontrol study. Eur J Pediatr 2001;160:333-8.

43 Jepsen P, Olsen ML, Mellemkjaer L, Olsen JH, Sorensen HT. A registry-based study of gender, fetal growth, and risk of Wilms tumor. Pediatr Hematol Oncol 2004;21:435-9.

44 Tatton-Brown K, Douglas J, Coleman K, Baujat G, Cole TR, Das S, Horn D, Hughes HE, Temple IK, Faravelli F, Waggoner D, Turkmen S, CormierDaire V, Irrthum A, Rahman N. Genotype-phenotype associations in Sotos syndrome: an analysis of 266 individuals with NSD1 aberrations. Am J Hum Genet 2005;77:193-204.

45 Rahman N. Mechanisms predisposing to childhood overgrowth and cancer. Curr Opin Genet Dev 2005;15:227-33. 
46 Thorburn MJ, Wright ES, Miller CG, Smith-Read EH. Exomphalosmacroglossia-gigantism syndrome in Jamaican infants. Am J Dis Child 1970;1 19:316-21.

47 Choyke PL, Siegel MJ, Oz O, Sotelo-Avila C, DeBaun MR. Nonmalignant renal disease in pediatric patients with Beckwith-Wiedemann syndrome. Am J Roentgenol 1998;171:733-7.

48 Sotelo-Avila C, Gonzalez-Crussi F, Fowler JW. Complete and incomplete forms of Beckwith-Wiedemann syndrome: their oncogenic potential. J Pediatr 1980:96:47-50.

49 Elliott M, Bayly R, Cole T, Temple IK, Maher ER. Clinical features and natural history of Beckwith-Wiedemann syndrome: presentation of 74 new cases. Clin Genet 1994:46:168-74.

50 Wiedemann HR. Frequency of Wiedemann-Beckwith syndrome in Germany; rate of hemihyperplasia and of tumours in affected children. Eur J Pediatr 1997; 156:251.

51 DeBaun MR, Tucker MA. Risk of cancer during the first four years of life in children from The Beckwith-Wiedemann Syndrome Registry. J Pediatr 1998; 132:398-400

52 Goldman M, Smith A, Shuman C, Caluseriu O, Wei C, Steele L, Ray P, Sadowski P, Squire J, Weksberg R, Rosenblum ND. Renal abnormalities in beckwith-wiedemann syndrome are associated with $11 \mathrm{p} 15.5$ uniparental disomy. J Am Soc Nephrol 2002;13:2077-84.

53 Porteus MH, Narkool P, Neuberg D, Guthrie K, Breslow N, Green DM, Diller L. Characteristics and outcome of children with Beckwith-Wiedemann syndrome and Wilms' tumor: a report from the National Wilms Tumor Study Group. J Clin Oncol 2000; 18:2026-31.

54 Weksberg R, Shuman C, Smith AC. Beckwith-Wiedemann syndrome. Am J Med Genet C Semin Med Genet 2005;137:12-23.

55 Gaston V, Le Bouc Y, Soupre V, Burglen L, Donadieu J, Oro H, Audry G, Vazquez MP, Gicquel C. Analysis of the methylation status of the KCNQ1OT and $\mathrm{H} 19$ genes in leukocyte DNA for the diagnosis and prognosis of Beckwith-Wiedemann syndrome. Eur J Hum Genet 2001;9:409-18.

56 Bliek J, Maas SM, Ruijter JM, Hennekam RC, Alders M, Westerveld A, Mannens MM. Increased tumour risk for BWS patients correlates with aberrant $\mathrm{H} 19$ and not KCNQ1OT1 methylation: occurrence of KCNQ1OT1 hypomethylation in familial cases of BWS. Hum Mol Genet 2001;10:467-76

57 Weksberg R, Nishikawa J, Caluseriu O, Fei YL, Shuman C, Wei C, Steele L, Cameron J, Smith A, Ambus I, Li M, Ray PN, Sadowski P, Squire J. Tumor development in the Beckwith-Wiedemann syndrome is associated with a variety of constitutional molecular $11 \mathrm{p} 15$ alterations including imprinting defects of KCNQ1OT1. Hum Mol Genet 2001;10:2989-3000.

58 DeBaun MR, Niemitz EL, McNeil DE, Brandenburg SA, Lee MP, Feinberg AP. Epigenetic alterations of $\mathrm{H} 19$ and LIT1 distinguish patients with BeckwithWiedemann syndrome with cancer and birth defects. Am J Hum Genet 2002;70:604-11.

59 Bliek J, Gicquel C, Maas S, Gaston V, Le Bouc Y, Mannens M. Epigenotyping as a tool for the prediction of tumor risk and tumor type in patients with Beckwith-Wiedemann syndrome (BWS). J Pediatr 2004; 145:796-9.

60 Cooper WN, Luharia A, Evans GA, Raza H, Haire AC, Grundy R, Bowdin SC, Riccio A, Sebastio G, Bliek J, Schofield PN, Reik W, Macdonald F, Maher ER. Molecular subtypes and phenotypic expression of Beckwith-Wiedemann syndrome. Eur J Hum Genet 2005;13:1025-32.

61 Rahman N. Mechanisms predisposing to childhood overgrowth and cancer. Curr Opin Genet Dev 2005; 15:227-33

62 Mariani S, lughetti L, Bertorelli R, Coviello D, Pellegrini M, Forabosco A Bernasconi S. Genotype/phenotype correlations of males affected by Simpson-Golabi-Behmel syndrome with GPC3 gene mutations: patient report and review of the literature. J Pediatr Endocrinol Metab 2003;16:225-32.

63 Pilia G, Hughes-Benzie RM, MacKenzie A, Baybayan P, Chen EY, Huber R, Neri G, Cao A, Forabosco A, Schlessinger D. Mutations in GPC3, a glypican gene, cause the Simpson-Golabi-Behmel overgrowth syndrome. Nat Genet 1996; 12:241-7.

64 Li M, Shuman C, Fei YL, Cutiongco E, Bender HA, Stevens C, Wilkins-Haug L, Day-Salvatore D, Yong SL, Geraghty MT, Squire J, Weksberg R. GPC3 mutation analysis in a spectrum of patients with overgrowth expands the phenotype of Simpson-Golabi-Behmel syndrome. Am J Med Genet 2001;102:161-8.

65 Brzustowicz LM, Farrell S, Khan MB, Weksberg R. Mapping of a new SGBS locus to chromosome Xp22 in a family with a severe form of SimpsonGolabi-Behmel syndrome. Am J Hum Genet 1999;65:779-83.

66 Grisaru S, Cano-Gauci D, Tee J, Filmus J, Rosenblum ND. Glypican-3 modulates BMP- and FGF-mediated effects during renal branching morphogenesis. Dev Biol 2001;231:31-46.

67 Song HH, Shi W, Xiang YY, Filmus J. The loss of glypican-3 induces alterations in Wnt signaling. J Biol Chem 2005;280:21 16-25.

68 Gonzalez AD, Kaya M, Shi W, Song H, Testa JR, Penn LZ, Filmus J. OCl-5/ GPC3, a glypican encoded by a gene that is mutated in the Simpson-GolabiBehmel overgrowth syndrome, induces apoptosis in a cell line-specific manner. J Cell Biol 1998;141:1407-14.

69 Chiao E, Fisher P, Crisponi L, Deiana M, Dragatsis I, Schlessinger D, Pilia G, Efstratiadis A. Overgrowth of a mouse model of the Simpson-Golabi-Behmel syndrome is independent of IGF signaling. Dev Biol 2002;243:185-206.

70 Hughes-Benzie RM, Pilia G, Xuan JY, Hunter AG, Chen E, Golabi M, Hurst JA, Kobori J, Marymee K, Pagon RA, Punnett HH, Schelley S, Tolmie JL, Wohlferd MM, Grossman T, Schlessinger D, MacKenzie AE. SimpsonGolabi-Behmel syndrome: genotype/phenotype analysis of 18 affected males from 7 unrelated families. Am J Med Genet 1996;66:227-34.

71 Lindsay S, Ireland M, O'Brien O, Clayton-Smith J, Hurst JA, Mann J, Cole T, Sampson J, Slaney S, Schlessinger D, Burn J, Pilia G. Large scale deletions in the GPC3 gene may account for a minority of cases of Simpson-GolabiBehmel syndrome. J Med Genet 1997;34:480-3.

72 Leck I, Record RG, McKeown T, Edwards JH. The incidence of malformations in Birmingham, England, 1950-1959. Teratology 1968;1:263-80.

73 Parker DA, Skalko RG. Congenital asymmetry: report of 10 cases with associated developmental abnormalities. Pediatrics 1969;44:584-9.

74 Higurashi M, liijima K, Sugimoto Y, Ishikawa N, Hoshina H, Watanabe N, Yoneyama $\mathrm{K}$. The birth prevalence of malformation syndromes in Tokyo infants: a survey of 14,430 newborn infants. Am J Med Genet 1980;6: 189-94

75 Green DM, Breslow NE, Beckwith JB, Norkool P. Screening of children with hemihypertrophy, aniridia, and Beckwith-Wiedemann syndrome in patients with Wilms tumor: a report from the National Wilms Tumor Study. Med Pediatr Oncol 1993;21:188-92.

76 Craft AW, Parker L, Stiller C, Cole M. Screening for Wilms' tumour in patients with aniridia, Beckwith syndrome, or hemihypertrophy. Med Pediatr Oncol 1995; $24: 231-4$

77 Hoyme HE, Seaver LH, Jones KL, Procopio F, Crooks W, Feingold M. Isolated hemihyperplasia (hemihypertrophy): report of a prospective multicenter study of the incidence of neoplasia and review. Am J Med Genet 1998:79:274-8

78 Niemitz EL, Feinberg AP, Brandenburg SA, Grundy PE, DeBaun MR. Children with idiopathic hemihypertrophy and beckwith-wiedemann syndrome have different constitutional epigenotypes associated with wilms tumor. Am J Hum Genet 2005;77:887-91.

79 Martin RA, Grange DK, Zehnbauer B, DeBaun MR. LITI and H19 methylation defects in isolated hemihyperplasia. Am J Med Genet $A$ 2005; 134:129-31.

80 Cohen MM. Asymmetry: molecular, biologic, embryopathic, and clinical perspectives. Am J Med Genet 2001;101:292-314.

81 Perlman M, Goldberg GM, Bar-Ziv J, Danovitch G. Renal hamartomas and nephroblastomatosis with fetal gigantism: a familial syndrome. J Pediatr 1973;83:414-18

82 Greenberg F, Copeland K, Gresik MV. Expanding the spectrum of the Perlman syndrome. Am J Med Genet 1988;29:773-6.

83 Perlman M, Levin M, Wittels B. Syndrome of fetal gigantism, renal hamartomas, and nephroblastomatosis with Wilms' tumor. Cancer 1975:35:1212-17.

84 Neri G, Martini-Neri ME, Katz BE, Opitz JM. The Perlman syndrome: familial renal dysplasia with Wilms tumor, fetal gigantism and multiple congenital anomalies. Am J Med Genet 1984;19:195-207.

85 Greenberg F, Stein F, Gresik MV, Finegold MJ, Carpenter RJ, Riccardi VM, Beaudet AL. The Perlman familial nephroblastomatosis syndrome. Am J Med Genet 1986;24:101-10.

86 Grundy RG, Pritchard J, Baraitser M, Risdon A, Robards M. Perlman and Wiedemann-Beckwith syndromes: two distinct conditions associated with Wilms' tumour. Eur J Pediatr 1992;151:895-8.

87 Chitty LS, Clark T, Maxwell D. Perlman syndrome - a cause of enlarged, hyperechogenic kidneys. Prenat Diagn 1998;18:1163-8.

88 Fahmy J, Kaminsky CK, Parisi MT. Perlman syndrome: a case report emphasizing its similarity to and distinction from Beckwith-Wiedemann and prune-belly syndromes. Pediatr Radiol 1998;28:179-82.

89 Henneveld HT, van Lingen RA, Hamel BC, Stolte-Dijkstra I, van Essen AJ. Perlman syndrome: four additional cases and review. Am J Med Genet 1999:86:439-46

90 Futreal PA, Coin L, Marshall M, Down T, Hubbard T, Wooster R, Rahman N, Stratton MR. A census of human cancer genes. Nat Rev Cancer 2004;4:177-83

91 Hanks S, Coleman K, Reid S, Plaja A, Firth H, Fitzpatrick D, Kidd A, Mehes K, Nash R, Robin N, Shannon N, Tolmie J, Swansbury J, Irrthum A, Douglas J, Rahman N. Constitutional aneuploidy and cancer predisposition caused by biallelic mutations in BUB1B. Nat Genet 2004;36:1159-61.

92 Nakamura Y, Nakashima H, Fukuda S, Hashimoto T, Maruyama M. Bilateral cystic nephroblastomas and multiple malformations with trisomy 8 mosaicism. Hum Pathol 1985;16:754-6.

93 Kajii T, Kawai T, Takumi T, Misu H, Mabuchi O, Takahashi Y, Tachino M Nihei F, Ikeuchi T. Mosaic variegated aneuploidy with multiple congenital abnormalities: homozygosity for total premature chromatid separation trait. Am J Med Genet 1998;78:245-9.

94 Kawame H, Sugio Y, Fuyama Y, Hayashi Y, Suzuki H, Kurosawa K, Maekawa K. Syndrome of microcephaly, Dandy-Walker malformation, and Wilms tumor caused by mosaic variegated aneuploidy with premature centromere division (PCD): report of a new case and review of the literature. J Hum Genet 1999:44:219-24.

95 Matsuura S, Ito E, Tauchi H, Komatsu K, Ikeuchi T, Kajii T. Chromosomal instability syndrome of total premature chromatid separation with mosaic variegated aneuploidy is defective in mitotic-spindle checkpoint. Am J Hum Genet 2000:67:483-6.

96 Matsuura S, Matsumoto $\mathrm{Y}$, Morishima K, Izumi H, Matsumoto $\mathrm{H}$, Ito E, Tsutsui K, Kobayashi J, Tauchi H, Kajiwara Y, Hama S, Kurisu K, Tahara H, Oshimura M, Komatsu K, Ikeuchi T, Kajii T. Monoallelic BUB1B mutations and defective mitotic-spindle checkpoint in seven families with premature chromatid separation (PCS) syndrome. Am J Med Genet A 2006; 140:358-67.

97 Tischkowitz MD, Hodgson SV. Fanconi anaemia. J Med Genet 2003:40:1-10.

98 Thompson LH. Unraveling the Fanconi anemia-DNA repair connection. Nat Genet 2005;37:921-2.

99 Rudkin TM, Foulkes WD. BRCA2: breaks, mistakes and failed separations. Trends Mol Med 2005;11:145-8. 
100 Meyer S, Fergusson WD, Oostra AB, Medhurst AL, Waisfisz Q, de Winter JP, Chen F, Carr TF, Clayton-Smith J, Clancy T, Green M, Barber L, Eden OB, Will AM, Joenje $H$, Taylor GM. A cross-linker-sensitive myeloid leukemia cell line from a 2-year-old boy with severe Fanconi anemia and biallelic FANCD1/BRCA2 mutations. Genes Chromosomes Cancer 2005;42:404-15.

101 Hirsch B, Shimamura A, Moreau L, Baldinger S, Hag-Alshiekh M, Bostrom B, Sencer S, D'Andrea AD. Association of biallelic BRCA2/FANCD1 mutations with spontaneous chromosomal instability and solid tumors of childhood. Blood 2004; 103:2554-9.

102 Wagner JE, Tolar J, Levran O, Scholl T, Deffenbaugh A, Satagopan J, Ben Porat L, Mah K, Batish SD, Kutler DI, MacMillan ML, Hanenberg $\mathrm{H}$, Auerbach AD. Germline mutations in BRCA2: shared genetic susceptibility to breast cancer, early onset leukemia, and Fanconi anemia. Blood 2004; 103:3226-9.

103 Ellis NA, Groden J, Ye TZ, Straughen J, Lennon DJ, Ciocci S, Proytcheva M, German J. The Bloom's syndrome gene product is homologous to RecQ helicases. Cell 1995;83:655-66.

104 German J. Bloom's syndrome. XX. The first 100 cancers. Cancer Genet Cytogenet 1997;93:100-6

105 Cairney AE, Andrews M, Greenberg M, Smith D, Weksberg R. Wilms tumor in three patients with Bloom syndrome. J Pediatr 1987;111:414-16.

106 Berger C, Frappaz D, Leroux D, Blez F, Vercherat M, Bouffet E, Jalbert $P$, Brunat-Mentigny M. [Wilms tumor and Bloom syndrome]. Arch Pediatr 1996;3:802-5.

107 Jain D, Hui P, McNamara J, Schwartz D, German J, Reyes-Mugica M. Bloom syndrome in sibs: first reports of hepatocellular carcinoma and Wilms tumor with documented anaplasia and nephrogenic rests. Pediatr Dev Pathol $2001 ; 4: 585-9$

108 Li FP, Fraumeni JF, Mulvihill JJ, Blattner WA, Dreyfus MG, Tucker MA Miller RW. A cancer family syndrome in twenty-four kindreds. Cancer Res 1988;48:5358-62.

109 Birch JM, Hartley AL, Tricker KJ, Prosser J, Condie A, Kelsey AM, Harris M, Jones $\mathrm{PH}$, Binchy $\mathrm{A}$, Crowther D. Prevalence and diversity of constitutional mutations in the p53 gene among 21 Li-Fraumeni families. Cancer Res 1994; $54: 1298-304$.

110 Evans DG, Birch JM, Thorneycroft M, McGown G, Lalloo F, Varley JM. Low rate of TP53 germline mutations in breast cancer/sarcoma families not fulfilling classical criteria for Li-Fraumeni syndrome. J Med Genet 2002;39:941-4

111 Li FP, Fraumeni JF. Prospective study of a family cancer syndrome. JAMA 1982;247:2692-4.

112 Hartley AL, Birch JM, Tricker K, Wallace SA, Kelsey AM, Harris M, Jones PH. Wilms tumor in the Li-Fraumeni cancer family syndrome. Cancer Genet Cytogenet 1993;67:133-5

113 Bardeesy N, Falkoff D, Petruzzi MJ, Nowak N, Zabel B, Adam M, Aguiar MC, Grundy P, Shows T, Pelletier J. Anaplastic Wilms' tumour, a subtype displaying poor prognosis, harbours p53 gene mutations. Nat Genet 1994;7:91-7.

114 Verselis SJ, Rheinwald JG, Fraumeni JF, Li FP. Novel p53 splice site mutations in three families with Li-Fraumeni syndrome. Oncogene 2000; 19:4230-5.

115 Birch JM, Alston RD, McNally RJ, Evans DG, Kelsey AM, Harris M, Eden OB, Varley $J M$. Relative frequency and morphology of cancers in carriers of germline TP53 mutations. Oncogene 2001;20:4621-8.

116 Olivier M, Eeles R, Hollstein M, Khan MA, Harris CC, Hainaut P. The IARC TP53 database: new online mutation analysis and recommendations to users. Hum Mutat 2002;19:607-14.

117 Evans SC, Mims B, McMasters KM, Foster CJ, deAndrade M, Amos Cl, Strong LC, Lozano G. Exclusion of a p53 germline mutation in a classic LiFraumeni syndrome family. Hum Genet 1998;102:681-6.

118 Chompret A, Brugieres L, Ronsin M, Gardes M, Dessarps-Freichey F, Abel A, Hua D, Ligot L, Dondon MG, Bressac-de Paillerets B, Frebourg T, Lemerle J, Bonaiti-Pellie C, Feunteun J. P53 germline mutations in childhood cancers and cancer risk for carrier individuals. Br J Cancer 2000;82:1932-7.

119 Jackson CE, Norum RA, Boyd SB, Talpos GB, Wilson SD, Taggart RT, Mallette LE. Hereditary hyperparathyroidism and multiple ossifying jaw fibromas: a clinically and genetically distinct syndrome. Surgery 1990; 108:1006-12.

120 Carpten JD, Robbins CM, Villablanca A, Forsberg L, Presciuttini S, BaileyWilson J, Simonds WF, Gillanders EM, Kennedy AM, Chen JD, Agarwal SK, Sood R, Jones MP, Moses TY, Haven C, Petillo D, Leotlela PD, Harding B, Cameron D, Pannett AA, Hoog A, Heath H, James-Newton LA, Robinson B, Zarbo RJ, Cavaco BM, Wassif W, Perrier ND, Rosen IB, Kristoffersson U, Turnpenny PD, Farnebo LO, Besser GM, Jackson CE, Morreau H, Trent JM, Thakker RV, Marx SJ, Teh BT, Larsson C, Hobbs MR. HRPT2, encoding parafibromin, is mutated in hyperparathyroidism-jaw tumor syndrome. Nat Genet 2002;32:676-80.

121 Yart A, Gstaiger M, Wirbelauer C, Pecnik M, Anastasiou D, Hess D, Krek W. The HRPT2 tumor suppressor gene product parafibromin associates with human PAF1 and RNA polymerase II. Mol Cell Biol 2005;25:5052-60.

122 Kakinuma A, Morimoto I, Nakano Y, Fujimoto R, Ishida O, Okada Y, Inokuchi N, Fujihira T, Eto S. Familial primary hyperparathyroidism complicated with Wilms' tumor. Intern Med 1994;33:123-6.

123 Teh BT, Farnebo F, Kristoffersson U, Sundelin B, Cardinal J, Axelson R, Yap A, Epstein M, Heath H, Cameron D, Larsson C. Autosomal dominant primary hyperparathyroidism and jaw tumor syndrome associated with renal hamartomas and cystic kidney disease: linkage to 1q21-q32 and loss of the wild type allele in renal hamartomas. $J$ Clin Endocrinol Metab 1996:81:4204-11.
124 WassifWS, FarneboF, Teh BT, Moniz CF, LiFY, Harrison JD, Peters TJ, Larsson C, Harris P. Genetic studies of a family with hereditary hyperparathyroidism-jaw tumour syndrome. Clin Endocrinol (Oxf) 1999;50:191-6.

125 Tan MH, Teh BT. Renal neoplasia in the hyperparathyroidism-jaw fumor syndrome. Curr Mol Med 2004:4:895-7.

126 Szabo J, Heath B, Hill VM, Jackson CE, Zarbo RJ, Mallette LE, Chew SL, Besser GM, Thakker RV, Huff V. Hereditary hyperparathyroidism-jaw tumor syndrome: the endocrine tumor gene HRPT2 maps to chromosome 1q21q31. Am J Hum Genet 1995;56:944-50.

127 Karlberg N, Jalanko H, Perheentupa J, Lipsanen-Nyman M. Mulibrey nanism: clinical features and diagnostic criteria. J Med Genet 2004;41:92-8

128 Karlberg S, Tiitinen A, Lipsanen-Nyman M. Failure of sexual maturation in Mulibrey nanism. N Engl J Med 2004;351:2559-60.

129 Avela K, Lipsanen-Nyman M, Idanheimo N, Seemanova E, Rosengren S, Makela TP, Perheentupa J, Chapelle AD, Lehesjoki AE. Gene encoding a new RING-B-box-Coiled-coil protein is mutated in mulibrey nanism. Nat Genet 2000;25:298-301.

130 Kallijarvi J, Lahtinen U, Hamalainen R, Lipsanen-Nyman M, Palvimo JJ, Lehesjoki AE. TRIM37 defective in mulibrey nanism is a novel RING finger ubiquitin E3 ligase. Exp Cell Res 2005;308:146-55.

131 Simila S, Timonen M, Heikkinen E. A case of Mulibrey nanism with associated Wilms' tumor. Clin Genet 1980;17:29-30.

132 Seemanova E, Bartsch O. Mulibrey nanism and Wilms tumor. Am J Med Genet 1999;85:76-8.

133 Nielsen J, Wohlert M. Chromosome abnormalities found among 34,910 newborn children: results from a 13-year incidence study in Arhus, Denmark. Hum Genet 1991;87:81-3.

134 Kinoshita M, Nakamura Y, Nakano R, Morimatsu M, Fukuda S, Nishimi Y, Hashimoto T. Thirty-one autopsy cases of trisomy 18: clinical features and pathological findings. Pediatr Pathol 1989;9:445-57.

135 Miller RW, Fraumeni JF, Manning MD. Association of Wilms's tumor with aniridia, hemihypertrophy and other congenital malformations. NEngl J Med 1964;270:922-7

136 Geiser CF, Schindler AM. Long survival in a male with 18-trisomy syndrome and Wilms' tumor. Pediatrics 1969;44:111-16.

137 Shanklin DR, Sotelo-Avila C. In situ tumors in fetuses, newborns and young infants. Biol Neonat 1969;14:286-316

138 Karayalcin G, Shanske A, Honigman R. Wilms' tumor in a 13-year old girl with trisomy 18. Am J Dis Child 1981;135:665-6.

139 Sheng WW, Soukup S, Bove K, Gotwals B, Lampkin B. Chromosome analysis of 31 Wilms' tumors. Cancer Res 1990;50:2786-93.

140 Faucette KJ, Carey JC. Trisomy 18 and Wilms' tumor-is there an association? Clin Res 1991;39:96.

141 Olson JM, Hamilton A, Breslow NE. Non-1 1p constitutional chromosome abnormalities in Wilms' tumor patients. Med Pediatr Oncol 1995:24:305-9.

142 Kullendorff CM, Wiebe T. Chromosomal aberrations in Wilms' tumour. Eur J Pediatr Surg 1997;7:286-7

143 Anderson CE, Punnett HH, Huff V, de Chadarevian JP. Characterization of a Wilms tumor in a 9-year-old girl with trisomy 18. Am J Med Genet 2003;121A:52-5.

144 Bove KE, Koffler H, McAdams AJ. Nodular renal blastema. Definition and possible significance. Cancer 1969;24:323-32

145 Rasmussen SA, Wong LY, Yang Q, May KM, Friedman JM. Populationbased analyses of mortality in trisomy 13 and trisomy 18. Pediatrics 2003;111:777-84.

146 Sweeney H, Pelegano J. Wilms tumor in a child with trisomy 13. J Pediatr Hematol Oncol 2000;22:171-2.

147 Conrad B, Dewald G, Christensen E, Lopez M, Higgins J, Pierpont ME. Clinical phenotype associated with terminal 2q37 deletion. Clin Genet 1995;48:134-9.

148 Viot-Szoboszlai G, Amiel J, Doz F, Prieur M, Couturier J, Zucker JN, Henry I, Munnich A, Vekemans $M$, Lyonnet $S$. Wilms' tumor and gonadal dysgenesis in a child with the 2q37.1 deletion syndrome. Clin Genet 1998:53:278-80.

149 Casas KA, Mononen TK, Mikail CN, Hassed SJ, Li S, Mulvihill JJ, Lin HJ, Falk RE. Chromosome 2q terminal deletion: report of 6 new patients and review of phenotype-breakpoint correlations in 66 individuals. Am J Med Genet 2004;130A:331-9.

150 Maes M, Lee PA, Jeffs RD, Sultan C, Migeon CJ. Phenotypic variation in a family with partial androgen insensitivity syndrome. Am J Dis Child 1980;134:470-3

151 Schimmenti LA, Cich JA, Gorlin RJ, Berry SA. Autosomal dominant inheritance of Wilms' tumor and branchial cleft anomalies. A new syndrome. Am J Hum Genet 1993:53:503.

152 Charles AK, Porter HJ, Sams V, Lunt P. Nephrogenic rests and renal abnormalities in Brachmann-de Lange syndrome. Pediatr Pathol Lab Med 1997; 17:209-19.

153 Maruiwa M, Nakamura Y, Motomura K, Murakami T, Kojiro M, Kato M, Morimatsu M, Fukuda S, Hashimoto T. Cornelia de Lange syndrome associated with Wilms' tumour and infantile haemangioendothelioma of the liver: report of two autopsy cases. Virchows Arch A Pathol Anat Histopathol 1988:413:463-8.

154 Martucciello G, Torre M, Belloni E, Lerone M, Pini PA, Cama A, Jasonni V. Currarino syndrome: proposal of a diagnostic and therapeutic protocol. J Pediatr Surg 2004;39:1305-11

155 Kusumakumary P, Ninan M, Chellam VG, Jacob R, Nair MK. Wilms tumor in a child with Down syndrome. J Pediatr Hematol Oncol 1995;17:276.

156 Fabia J, Drolette M. Malformations and leukemia in children with Down's syndrome. Pediatrics 1970;45:60-70.

157 Solomon LM. Epidermal nevus syndrome. Mod Probl Paediatr 1975: 17:27-30. 
158 Pawlaczyk M, Pietrzak S, Bowszyc-Dmochowska M. [Epidermal nevus syndrome - bi-symptom type]. Chir Narzadow Ruchu Ortop Pol 1996:61:505-10.

159 Courville $\mathbf{P}$, Thomine E, Surlemont $Y$, Hemet J, Metayer J, Lauret $P$. [Epidermal nevus associated with a type I neurofibromatosis and a nephroblastoma: a new epidermal nevus syndrome?]. Ann Pathol 2000;20:616-19.

160 Drouin V, Vannier JP, Moirot H, Mitrofanoff P, Tron P. [Nephroblastoma and fragile $X$ syndrome]. Arch Fr Pediatr 1992:49:477.

161 Drut R, Pollono D, Drut RM. Bilateral nephroblastoma in familial Hay-Wells syndrome associated with familial reticulate pigmentation of the skin. Am J Med Genet 2002; 110:164-9.

162 Steward VW, Jevtic MM. Derangement of neuronal migration in a child with multiple congenital anomalies, two congenital neoplasms, without apparent chromosomal abnormalities. J Neuropathol Exp Neurol 1979;38:259-85.

163 Perry TL, Hardwick DF, Lowry RB, Hansen S. Hyperprolinaemia in two successive generations of a North American Indian family. Ann Hum Genet 1968;31:401-7.

164 Early CK, Rosen D, Mirza M. The coexistence of Wilms' tumor and imperforate anus with rectourethral fistula. J Pediatr Surg 1981;16:756-7.

165 Shashikumar VL, Somers LA, Pilling GP, Cresson SL. Wilms' tumor in the horseshoe kidney. J Pediatr Surg 1974;9:185-9.

166 Kadotani T, Watanabe J, Shimoda H. A Chromosome study of a patient with Wilms' tumor. Proc Jpn Acad Ser B 1984;60:191-4.

167 Zhou XP, Woodford-Richens K, Lehtonen R, Kurose K, Aldred M, Hampel H, Launonen V, Virta S, Pilarski R, Salovaara R, Bodmer WF, Conrad BA, Dunlop M, Hodgson SV, Iwama T, Jarvinen H, Kellokumpu I, Kim JC, Leggett B, Markie D, Mecklin JP, Neale K, Phillips R, Piris J, Rozen P, Houlston RS, Aaltonen LA, Tomlinson IP, Eng C. Germline mutations in BMPRIA/ALK3 cause a subset of cases of juvenile polyposis syndrome and of Cowden and Bannayan-Riley-Ruvalcaba syndromes. Am J Hum Genet 2001;69:704-11.

168 Mankad VN, Gray GF, Miller DR. Bilateral nephroblastomatosis and Klippel Trenaunay syndrome. Cancer 1974;33:1462-7.

169 Ehrich JH, Ostertag H, Flatz S, Kamran D. Bilateral Wilms's tumour in Klippel-Trenaunay syndrome. Arch Dis Child 1979;54:405.

170 Lapunzina P, Gairi A, Delicado A, Mori MA, Torres ML, Goma A, Navia M, Pajares IL. Macrocephaly-cutis marmorata telangiectatica congenita: report of six new patients and a review. Am J Med Genet A 2004;130:45-51.

171 Newbold SG, Shafer AD, Goodwin CD, Nanagas VN, Dimlich SH. Stage III Wilms' tumor of a solitary kidney in a patient with Marfan's syndrome: a 5yr survival. J Pediatr Surg 1982;17:841-2.

172 Williams DK, Carlton DR, Green SH, Pearman K, Cole TR. Marshall-Smith syndrome: the expanding phenotype. J Med Genet 1997;34:842-5.

173 Yaris N, Aynaci FM, Kalyoncu M, Odemis E, Okten A. Wilms' tumor in a case with Mobius' syndrome associated with arthrogryposis and mega cisterna magna. J Child Neurol 2004;19:67-70.

174 Kimura A, Kudo E, Hamamoto Y, Hirai H, Watanabe K. Sympus monopus accompanied by nephroblastoma--A case report. Acta Pathol Jpn 1975;25:375-84

175 Ito F, Watanabe Y, Ito T. Synchronous occurrence of Wilms tumor and ganglioneuroblastoma in a child with neurofibromatosis. Eur J Pediatr Surg 1997;7:308-10.

176 Eiferman RA. Association of Wilms' tumor with Peter's anomaly. Ann Ophthalmol 1984;16:933-4.

177 Camassei FD, Jenkner A, Bertini E, Bosman C, Donfrancesco A, Boldrini R. Pierre Robin syndrome and Wilms tumor: an unusual association. Med Pediatr Oncol 2000;35:83-4.

178 Athale UH, Warrier R. Poland's syndrome and Wilms tumor: an unusual association. Med Pediatr Oncol 1998;30:67-8.

179 Haupt R, Sansone R, Dallorso S, Garre ML, Corciulo P. [Wilms' tumor, polycythemia, ichthyosis and ear malformations: a new syndrome?]. Pediatr Med Chir 1992;14:215-17.

180 Coppes MJ, Sohl H, Teshima IE, Mutirangura A, Ledbetter DH, Weksberg R. Wilms tumor in a patient with Prader-Willi syndrome. J Pediatr 1993; 122:730-3.

181 Bruckheimer E, Abrahamov A. Russell-Silver syndrome and Wilms tumor. J Pediatr 1993;122:165-6.

182 Grether P, Carnevale A, Pasquel P. Wilms' tumor in an infant with tuberous sclerosis. Ann Genet 1987;30:183-5.

183 Hasle H, Olsen JH, Nielsen J, Hansen J, Friedrich U, Tommerup N. Occurrence of cancer in women with Turner syndrome. $\mathrm{Br} J$ Cancer 1996;73:1 156-9

184 Say B, Balci S, Tuncbilek E. 45,XO Turner's syndrome, Wilm's tumor and imprforate anus. Humangenetik 1971;12:348-50.

185 Reinberg Y, Anderson GF, Franciosi R, Manivel C, Dehner LP, Burke BA. Wilms tumor and the VATER association. J Urol 1988;140:787-9.

186 Huson SM, Harper PS, Compston DA. Von Recklinghausen neurofibromatosis. A clinical and population study in south-east Wales. Brain 1988;111:1355-81.

187 Friedman JM, Birch PH. Type 1 neurofibromatosis: a descriptive analysis of the disorder in 1,728 patients. Am J Med Genet 1997;70:138-43.

188 Sorensen SA, Mulvihill JJ, Nielsen A. Long-term follow-up of von Recklinghausen neurofibromatosis. Survival and malignant neoplasms. N Engl J Med 1986;314:1010-15.

189 Narod SA, Stiller C, Lenoir GM. An estimate of the heritable fraction of childhood cancer. Br J Cancer 1991;63:993-9.

190 Hersh JH, Cole TR, Bloom AS, Bertolone SJ, Hughes HE. Risk of malignancy in Sotos syndrome. J Pediatr 1992;120:572-4.

191 Tatton-Brown K, Douglas J, Coleman K, Baujat G, Cole TR, Das S, Horn D, Hughes HE, Temple IK, Faravelli F, Waggoner D, Turkmen S, Cormier-
Daire V, Irrthum A, Rahman N. Genotype-phenotype associations in Sotos syndrome: an analysis of 266 individuals with NSD 1 aberrations. Am J Hum Genet 2005;77:193-204.

192 Swerdlow AJ, Hermon C, Jacobs PA, Alberman E, Beral V, Daker M, Fordyce A, Youings S. Mortality and cancer incidence in persons with numerical sex chromosome abnormalities: a cohort study. Ann Hum Genet 2001;65:177-88.

193 Miller RW, Fraumeni JF, Manning MD. Association of Wilms's tumor with aniridia, hemihypertrophy and other congenital malformations. NEngl J Med 1964;270:922-7.

194 Berry CL, Keeling J, Hilton C. Coincidence of congenital malformation and embryonic tumours of childhood. Arch Dis Child 1970;45:229-31.

195 Mark HF, Wyandt H, Pan A, Milunsky JM. Constitutional partial 1q trisomy mosaicism and Wilms tumor. Cancer Genet Cytogenet 2005; 162:166-71.

196 Bache I, Hasle H, Tommerup N, Olsen JH. Population-based study of cancer among carriers of a constitutional structural chromosomal rearrangement. Genes Chromosomes Cancer 2006;45:231-46.

197 Hewitt M, Lunt PW, Oakhill A. Wilms' tumour and a de novo $(1 ; 7)$ translocation in a child with bilateral radial aplasia. J Med Genet $1991 ; 28: 411-12$

198 Barber JC, Thomas NS, Collinson MN, Dennis NR, Liehr T, Weise A, Belitz B, Pfeiffer L, Kirchhoff M, Krag-Olsen B, Lundsteen C. Segmental haplosufficiency: transmitted deletions of $2 \mathrm{p} 12$ include a pancreatic regeneration gene cluster and have no apparent phenotypic consequences. Eur J Hum Genet 2005; 13:283-91.

199 Hoban PR, Cowen RL, Mitchell EL, Evans DG, Kelly M, Howard PJ, Heighway J. Physical localisation of the breakpoints of a constitutional translocation $+(5 ; 6)(\mathrm{q} 21 ; \mathrm{q} 21)$ in a child with bilateral Wilms' tumour. J Med Genet 1997;34:343-5.

200 Cavicchioni O, Gomes DM, Leroy B, Vialard F, Hillion Y, Selva J, Ville Y. Prenatal diagnosis of de novo (7;19)(q1 1.2; q13.3) translocation associated with a thick corpus callosum and Wilms tumor of the kidneys. Prenat Diagn 2005:25:876-8.

201 Bernard JL, Baeteman MA, Mattei JF, Raybaud C, Giraud F. Wilms' tumor, malformative syndrome, mental retardation and de novo constitutional translocation, $\mathrm{t}(7 ; 13)(\mathrm{q} 36 ; \mathrm{q} 13)$. Eur J Pediatr 1984;141:175-7.

202 Alvarez-Franco M, Bale AE, Reyes-Mugica M. Expanding the spectrum of Gorlin Syndrome: Wilms tumor in a patient with 9q22.3 deletion. Pediatr Dev Pathol 2000;3:306-11.

203 Betts DR, Greiner J, Feldges A, Caflisch U, Niggli FK. Constitutional balanced chromosomal rearrangements and neoplasm in children. J Pediatr Hematol Oncol 2001;23:582-4.

204 Stratton RF, Lazarus KH, Ritchie EJ, Bell AM. Deletion (11)(q14.1q21). Am J Med Genet 1994;49:294-8.

205 Rapley EA, Hargrave D, Persinguhe N, Barfoot R, Moore I, Radford M, Stratton MR, Rahman N, Pritchard-Jones K. Case of interstitial 12q deletion in association with Wilms tumor. Am J Med Genet 2001;104:246-9.

206 Turner AM, Rosier M, Cohn R, Turner G, Battese K, Yip M. 'Weaver syndrome" and Wilms tumour in a child with an unbalanced cryptic translocation. 7 Individuals with mental retardation in the one family due to translocation - t(12;22)(q24.33;q13.31). International Congress of Human Genetics 2001:P0430.

207 Schluth C, Mattei MG, Mignon-Ravix C, Salman S, Alembik Y, Willig J, Ginglinger $E$, Jeandidier E. Intrachromosomal triplication for the distal part of chromosome 15q. Am J Med Genet A 2005;136:179-84.

208 Hu J, McPherson E, Surti U, Hasegawa SL, Gunawardena S, Gollin SM. Tetrasomy $15 q 25.3 \rightarrow$ qter resulting from an analphoid supernumerary marker chromosome in a patient with multiple anomalies and bilateral Wilms tumors. Am J Med Genet 2002;113:82-8

209 Kakati S, Xiao H, Siddiqui SY, Sreekantaiah C, Weier HU, Green DM, Fisher JE, Allen JE. Constitutional extra chromosomal element in a family with Wilms' tumor. Hum Genet 1991;87:183-8.

210 Stiller CA, Lennox EL, Wilson LM. Incidence of cardiac septal defects in children with Wilms' tumour and other malignant diseases. Carcinogenesis 1987:8:129-32

211 Schumacher R, Mai A, Gutjahr P. Association of rib anomalies and malignancy in childhood. Eur J Pediatr 1992;151:432-4.

212 Oliveira-Filho AG, Carvalho MH, Sbragia-Neto L, Miranda ML, BustorffSilva JM, de Oliveira ER. Wilms tumor in a prenatally diagnosed multicystic kidney. J Urol 1997;158:1926-7.

213 Neville H, Ritchey ML, Shamberger RC, Haase G, Perlman S, Yoshioka T. The occurrence of Wilms tumor in horseshoe kidneys: a report from the National Wilms Tumor Study Group (NWTSG). J Pediatr Surg 2002:37:1134-7.

214 Narchi H. Risk of Wilms' tumour with multicystic kidney disease: a systematic review. Arch Dis Child 2005;90:147-9.

215 Kramer S, Meadows AT, Jarrett P. Racial variation in incidence of Wilms tumor: relationship to congenital anomalies. Med Pediatr Oncol 1984; 12:401-5.

216 Bonaiti-Pellie C, Chompret A, Tournade MF, Hochez J, Moutou C, Zucker JM, Steschenko D, Brunat-Mentigny M, Roche H, Tron P. Genetics and epidemiology of Wilms' tumor: the French Wilms' tumor study. Med Pediatr Oncol 1992;20:284-91.

217 Merks JH, Smets AM, Van Rijn RR, Kobes J, Caron HN, Maas M, Hennekam RC. Prevalence of rib anomalies in normal Caucasian children and childhood cancer patients. Eur J Med Genet 2005;48:113-29.

218 The Wilms Tumour Surveillance Working Group. Surveillance for Wilms tumour in at-risk individuals - pragmatic recommendations for best practice, 2005: http://www.icr.ac.uk/research/research_sections/cancer_genetics/ cancer_genetics_teams/childhood_cancer_genetics/ Wilms_tumour_surv_group/2147.pdf. 